\title{
Evaluating Cytotoxic Potential of the Fruit and the Leaf Extracts of Sambucus ebulus (L.) on MCF7 and AGS Cell Lines
}

\author{
Farzaneh Rasouli Asl ${ }^{1}$ (D), Ali Barzegar ${ }^{1}$ (D), Mohammad Ali Ebrahimzadeh ${ }^{2 *}$ (D)
}

1. Departments of Basic Sciences, Sari Agricultural Sciences and Natural Resources University, Sari, Iran

2. Pharmaceutical Sciences Research Center, Hemoglobinopathy Institute, School of Pharmacy, Mazandaran University of Medical Sciences, Sari, Iran.

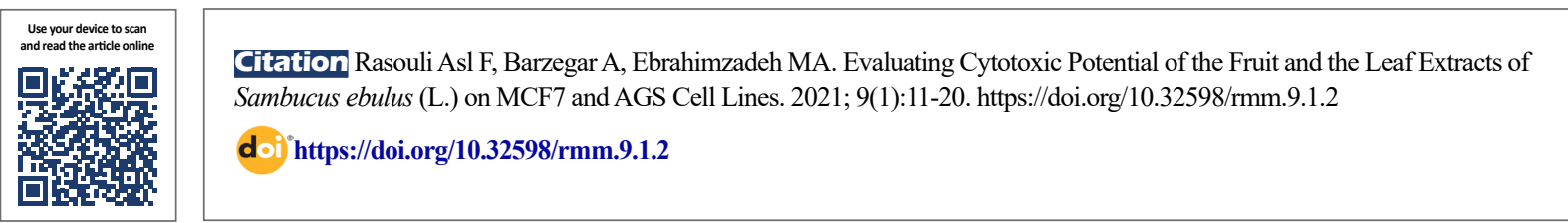

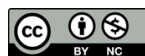

Article Type:

Research Paper

Article info:

Received: 9 Jan 2021

Revised: 28 Jan 2021

Accepted: 18 Feb 2021

Keywords:

AGS, HPLC, MCF-7,

MTT, Plant extract,

Sambucus ebulus

\begin{abstract}
A B S T RA C T
Background: Breast and stomach cancers are the most common malignancies in Iranian females and males, respectively. Enriching with phytochemicals that have antioxidant and cytotoxic activities, extracts from dwarf elder (Sambucus ebulus L.) holds promises to be used for alternative medication.

Materials and Methods: We investigated the cytotoxic and antiproliferative activities of the leaf and the fruit ethyl-acetate (EA), as well as the methanolic $(\mathrm{MeOH})$ extracts of dwarf elder upon treatment of the MCF-7 and AGS cells. Twenty-seven concentration series ranging from 10 to $2000 \mu \mathrm{g} / \mathrm{mL}$ were administered to the cells, and their growth inhibitory potential was assessed using MTT assay. The potential anticancer compounds of the extracts were quantified applying an improved highperformance liquid chromatography (HPLC).

Results: All extracts showed positive dose-dependent cytotoxic activities on both cell lines. The EA extracts demonstrated more cytotoxicity compared to those of the $\mathrm{MeOH}$ ones $(\mathrm{P}<0.0001)$. The leaf EA extract showed IC50 values of 65 and $50 \mu \mathrm{g} / \mathrm{mL}$, while those of the fruit were estimated as 58 and $50 \mu \mathrm{g} / \mathrm{mL}$ on the MCF-7 and AGS cells, respectively. The AGS cell line showed more susceptibility to all extracts tested compared to the MCF-7. MeOH extracts caused only a maximum of $\sim 20 \%$ reduction in cell viability at $2000 \mu \mathrm{g} / \mathrm{mL}$ concentration. According to the HPLC analysis, leaf extracts contained phenolic compounds, including $\mathrm{p}$ - coumaric acid ( $0.10 \mathrm{mg}$ per g powder), rutin $(0.07 \mathrm{mg}$ per g powder), and quercetin ( $0.02 \mathrm{mg}$ per g powder).

Conclusion: EA extract of the fruit shows the highest cytotoxicity: reducing $35.3 \%$ viability of the AGS cells with $10 \mu \mathrm{g} / \mathrm{mL}$ concentration. It can be considered a potential chemopreventive agent for cancer therapies. However, $\mathrm{MeOH}$ extracts with far low cytotoxicity or non-cytotoxic at some concentrations would be an appropriate candidate for preventing tumor growth without affecting neighboring normal cells.
\end{abstract}

* Corresponding Author:

Mohammad Ali Ebrahimzadeh, PhD.

Address: Pharmaceutical Sciences Research Center, Hemoglobinopathy Institute, School of Pharmacy, Mazandaran University of Medical Sciences, Sari, Iran. Phone: +98 (113) 3044000

E-mail: zadeh20@gmail.com 


\section{Introduction}

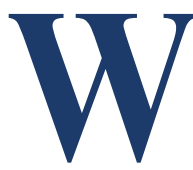

ith 13776 new cases and 3526 deaths every year, cancer accounts for the second main chronic disease and the third leading cause of mortality in Iran [1]. It is a complex disease influenced by genetic and epigenetic abnormalities, as well as environmental risk factors $[1,2]$. Breast and stomach cancers are the most common malignancies of Iranian females and males, respectively. They have heterogeneous geographical distributions in the country [3-7]. Despite significant progress on the molecular and cellular mechanisms of cancer etiology, it still constitutes a serious health problem, especially in developing countries like Iran, where the cancer is mainly attributed to lifestyle changes, obesity, smoking habit, and pesticide exposure [8-10]. Different approaches such as surgery, radiotherapy, and chemotherapy or a combination of them applying to treat cancers are costly and often cause adverse effects. Exploring new therapeutic compounds with targeted efficacy on neoplastic cells and decreased side effects on normal healthy tissues have priority in tumor medications.

Medicinal plants were used in folk medicine to treat various diseases, and they have shown promising results to be used against neoplastic growth $[11,12]$. Medicinal plants are usually rich resources for bioactive compounds with antineoplastic properties along with other accompanying compounds. They mostly have no cytotoxic side effects on normal cells [13]. Dwarf elder, also known as elderberries (Sambucus ebulus L.), belonged to the family Adoxaceae has a long history in folk medicine. Different parts of S. ebulus have been used as the therapeutic and the nutritional regimen in different world regions, from Western Europe to the Middle East [14]. A variety of phytochemical compounds have been detected in different parts of this plant, such as rhizomes, leaves, fruits, and flowers. Biochemical analyses confirmed differential nutritional and therapeutic values of different parts of the plant. Nutritional compounds of the plant are attributed to its minerals, fibers, vitamins, and sugars. Sambucus species are also rich with important secondary metabolites such as anthocyanin, flavonoids, polyphenols, triterpenes, tannins, and lectins, most of which have medicinal values, including antioxidant, anti-inflammatory, analgesic, antimicrobial, anticancer, neuroprotective, and antidepressant activities [15-19]. Quercetin, a polyphenolic compound, can inhibit tumor growth through induction of apoptosis in a variety of cancer cell lines [20-22]. It can inhibit the development of gastric, esophageal, and ovarian cancers [23]. 3,3',4',5,7-Pentahydroxyflavone-3-rhamnoglucoside (rutin) is a diglyco- side of quercetin, which is the predominant flavonol type of flavonoid in foods. Even though rutin and quercetin share several biological activities, the antiproliferative effects of rutin and quercetin on cancer cell lines were significantly different [24]. Chlorogenic acid (CGA) has antioxidant and anticancer properties based on its biological and pharmacological activities [25]. Caffeic acid (3,4-dihydroxy cinnamic acid) is another essential phenolic compound with prooxidant activity that shows anticancer properties similar to proapoptotic compounds [26]. Ethanolic and methanolic $(\mathrm{MeOH})$ extracts of Sambucus plants are rich in polyphenolic compounds like anthocyanin and flavonoids capable of scavenging reactive molecules like hydrogen peroxide, 1, 1-diphenyl-2-picrylhydrazyl (DPPH), and other free radicals, thus prevent the formation of DNA adducts and likely neoplastic growth [27]. Additionally, these compounds could prevent the teratogenicity of albendazole as studied in a mouse model [28].

Sambucus spp. contains several lectin glycoproteins stored in different parts of the plant. Some lectin proteins known as ebulin toxins have inhibitory activity against protein synthesis and have been isolated from different parts of S. ebulus, such as fruits (ebulin f), leaves (ebulin 1), and rhizomes (ebulin r1 and r2). S. ebulus also contains other lectin isoforms (B-B type) with potential cell-agglutinating activity, like SELld in leaves, SELlm in roots, and SELfd in fruits [29, 18]. The cell agglutination activities of the lectins can potentially be used for the agglutination of the neoplastic cells, especially in liquid tumors like leukemia and lymphoma [30]. Here, we studied cytotoxic and antiproliferative activities of a broad concentration range of the fruit and the leaf ethyl-acetate (EA) and $\mathrm{MeOH}$ extracts of S. ebulus on AGS and MCF-7 cell lines. Also, high-performance liquid chromatography (HPLC) was used to quantify the secondary metabolites from the extracts with potential anticancer activity.

\section{Materials and Methods}

\section{Plant materials}

Dwarf elder (Sambucus ebulus L.) plants were collected from the Southern coastal areas of the Caspian Sea (Sari, Mazandaran Province, Iran) during April-May of 2019. They were authenticated by a pharmacognosy expert at the Pharmacology Department (Mazandaran University of Medical Sciences), and a voucher thereof (No. 16-93) was deposited at the herbarium in Sari School of Pharmacy. Leaves and fruits of the plants were air-dried in the shade and grounded into a fine powder using a 
grinder. $\mathrm{MeOH}$ and EA extracts were obtained using the maceration method [19, 27]. Briefly, the dried powder of the leaves and the fruits were individually mixed with $\mathrm{MeOH}$ and EA solvents $(1: 1.5 \mathrm{~W} / \mathrm{V})$ and incubated at room temperature for $24 \mathrm{~h}$ with occasional stirring. The solvents were removed, and the step was repeated three times. The solution was subjected to evaporation in a vacuum rotary evaporator at $35^{\circ} \mathrm{C}$ and then was placed in a freeze drier for complete solvent removal. The crude powder of the extract was kept at $4^{\circ} \mathrm{C}$ away from light. An integrative concentration ranges of the plant extracts, including $10,20,30,40,50,60,70,80,90,100,200,300$, $400,500,600,700,800,900,1000,1200,1300,1400$, $1500,1600,1700,1800$ and $2000 \mu \mathrm{g} / \mathrm{mL}$ were prepared by dissolving crude extracts in RPMI-1640. Cells treated with $0.5 \%(\mathrm{v} / \mathrm{v})$ Dimethyl sulfoxide (DMSO) was used as solvent and volumetric concentration was considered as control (zero concentration of extract).

\section{Cell lines and culture media}

MCF7 and AGS cells (Pasteur institute, Iran) were grown in Roswell Park Memorial Institute (RPMI-1640) culture medium containing $10 \%(\mathrm{v} / \mathrm{v})$ fetal bovine serum (FBS) $100 \mathrm{U} / \mathrm{mL}$ penicillin and $100 \mu \mathrm{g} / \mathrm{mL}$ streptomycin (Gibco, US). Culture flasks were maintained at $37 \mathrm{oC}$ in $5 \% \mathrm{CO} 2$ and $95 \%$ humidified atmosphere at a $\mathrm{CO} 2$ incubator. Subcultivation of the cells was organized upon $80 \%$ confluency. The culture medium was poured off, and the cells were trypsinized (500 $\mu \mathrm{L}$ of $0.025 \%$ trypsin in PBS/ EDTA solution) to detach from the flask. The trypsin was inactivated by the addition of the fresh culture medium. The cells were washed two times with phosphate-buffered saline (PBS) and were collected by centrifugation at $1500 \mathrm{rpm}$ for $15 \mathrm{~min}\left(4^{\circ} \mathrm{C}\right)$. Cell counting was done using the hemocytometer counter and trypan blue method. Approximately, $1 \times 106$ cells were subcultured into a fresh growth medium and were maintained at $37^{\circ} \mathrm{C}$ under $5 \% \mathrm{CO} 2$ and $95 \%$ air.

\section{MTT assay}

Antiproliferative activity of the extracts were studied using MTT (3- [4,5-dimethylthiazol-2-yl]-2,5-diphenyl tetrazolium bromide) colorimetric method. In MTT assay, mitochondrial enzyme reduces soluble MTT into an insoluble color formazan product in viable tumor cells, which may be measured spectrophotometrically. Briefly, $200 \mu \mathrm{L}$ of the cell suspension $(5 \times 103$ cells $/ \mathrm{mL})$ were seeded in 96-well plates and incubated for $24 \mathrm{~h}$ to adhere to the plate and hereafter subjected to various concentration ranges of the extracts. The cells were incubated with different concentrations of the plant extracts rang- ing from 10 to $2000 \mu \mathrm{g} / \mathrm{mL}$ for $48 \mathrm{~h}$. Ten $\mu \mathrm{L}$ MTT (5 $\mathrm{mg} / \mathrm{mL}$ in phosphate buffer solution) was mixed into the wells, and incubation continued for another $4 \mathrm{~h}$ in the dark. MTT solution was gently replaced with $150 \mu \mathrm{L}$ DMSO to dissolve formazan crystals. The optical density of the chromogenic purple formazan was recorded by an ELISA apparatus (Bio-Rad) at $570 \mathrm{~nm}$. IC50 (50\% inhibitory concentration) of the extract was estimated using Equation 1:

1. Cytotoxicity $(\%)=100 \times(O D$ of untreated cells $-O D$ of treated cells)/OD of untreated cells

\section{Statistical analysis}

Each treatment was scheduled as three technical and two biological controls using a completely randomized design (CRD), and the results were analyzed using 1-way ANOVA (analysis of variance). Statistical analyzes were carried out using SAS Software Ver. 6.12, and $\mathrm{P}<0.05$ was considered the significant level. Additionally, the Quest Graph ${ }^{\mathrm{TM}}$ IC50 Calculator was complementarily done to precisely find the points needed to draw bestfitting regression line, particularly around the inflection point [31], using Equation 2:

$$
\begin{aligned}
& \text { 2. } Y=\operatorname{Min}+\frac{\text { Max-Min }}{1+\left(\frac{X}{1 C 50}\right. \text { Hil coefficient }} \\
& \text { High-performance liquid chromatography }
\end{aligned}
$$

Flavonoid or phenolic acid contents of the extracts with potential anticancer activities were resolved using an improved HPLC method. The HPLC machine had a solvent delivery system (K-1001) equipped with a Rheodyne injection valve ( $20 \mu \mathrm{L}$ sample loop inserted) and a model K-2600 UV-vis spectrophotometric detector set at $275 \mathrm{~nm}$ [24].

\section{Results}

Cytotoxicity of the leaf and the fruit $\mathrm{MeOH}$, as well as EA extracts of dwarf elder plant ranging from 10-2000 $\mu \mathrm{g} / \mathrm{mL}$, was investigated on MCF-7 and AGS cell lines using MTT assay. The leaf EA extract showed positive dose-dependent cytotoxic activities on both cell lines, with more cytotoxicity on the AGS cell line. A significant decrease in cell viability was predominantly appeared in concentrations between 0 and $100 \mu \mathrm{g} / \mathrm{mL}$ with the IC50 values of 65 and $50 \mu \mathrm{g} / \mathrm{mL}$ for MCF-7 and AGS cell lines, respectively. The least proliferation rates of $22.9 \%$ and $7.2 \%$ were detected following treatment of MCF7 and AGS cell lines with $2000 \mu \mathrm{g} / \mathrm{mL}$ of the extract, respectively. Similarly, the fruit EA extract showed posi- 


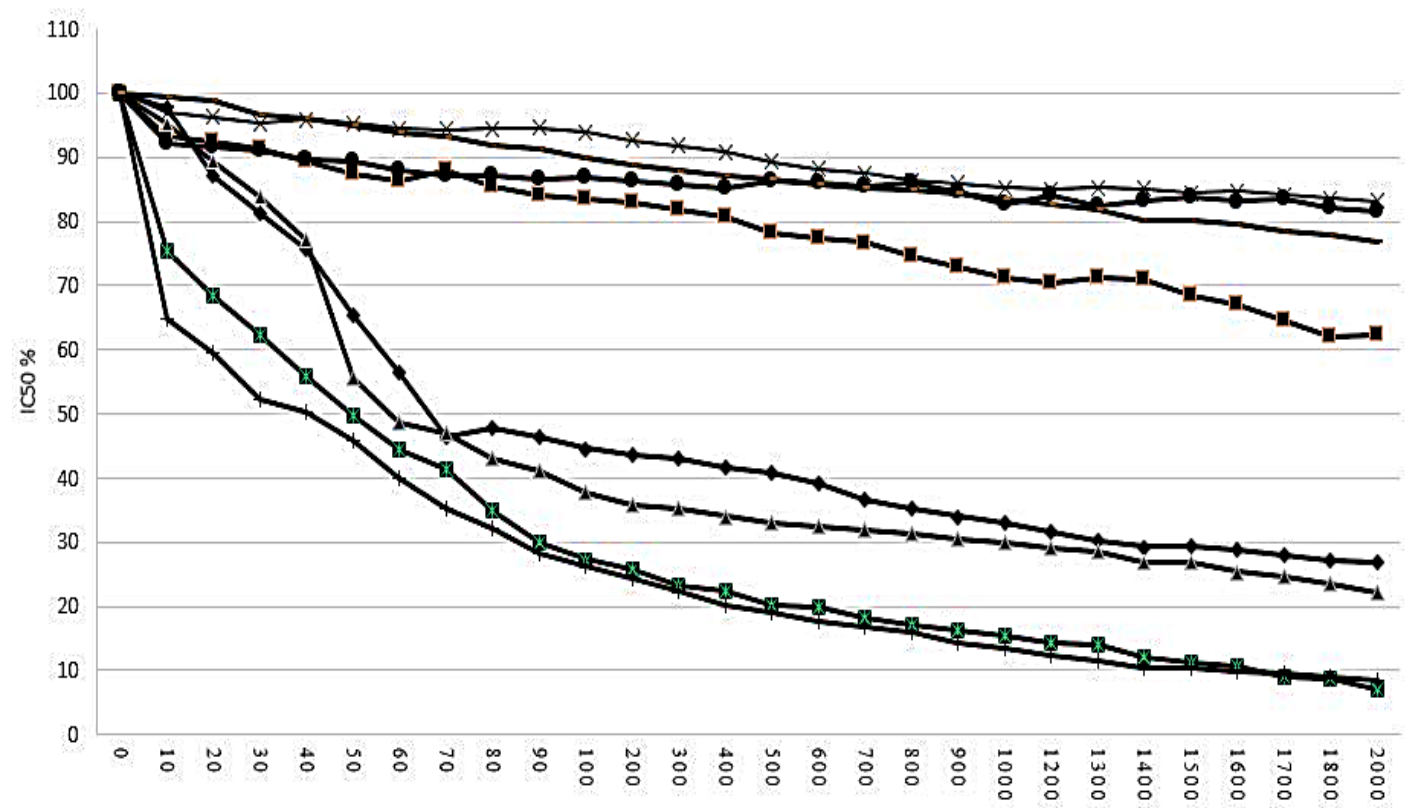

CONCENTRATION, MICROGRAM/ML

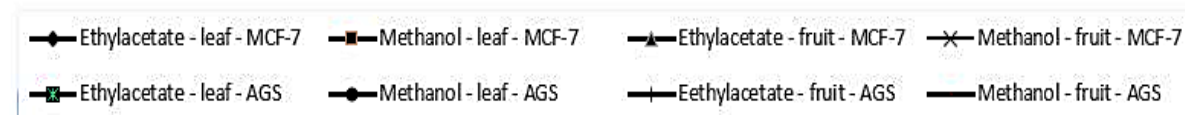

Figure 1. Growth inhibition rate of the AGS and MCF-7 cells following treatment with different concentrations of the leaf and the fruit $\mathrm{MeOH}$ and EA extracts of the dwarf elder plant

The $\mathrm{x}$-axis shows the concentration of the extract in $\mu \mathrm{g} / \mathrm{mL}$, and the $\mathrm{y}$-axis shows the percentage of IC50. Zero concentration of the extract is considered the control contains RPMI-1640 (Roswell Park Memorial Institute) with 0.5\% DMSO. ${ }^{*} \mathrm{P}<0.0001$ compared to control.

tive dose-dependent cytotoxic activities, with greater growth arrest on the AGS cell line. The toxicity graph is composed of an inflection point at $50 \mu \mathrm{g} / \mathrm{mL}$, a gentle slope at concentration ranges of $>50 \mu \mathrm{g} / \mathrm{mL}$, but a sharp slope at the concentrations of $<50 \mu \mathrm{g} / \mathrm{mL}$. The IC50 values of the fruit EA extract were $58 \mu \mathrm{g} / \mathrm{mL}$ and $50 \mu \mathrm{g} /$ $\mathrm{mL}$ for MCF-7 and AGS cells, respectively. Minimum viability percentages of $22.05 \%$ and $8.6 \%$ were detected following treatment of the MCF-7 and AGS cell with the $2000 \mu \mathrm{g} / \mathrm{mL}$ concentration. The $\mathrm{MeOH}$ extract of the fruits had much lower cytotoxicity compared to the EA one. This extract could cause the maximum growth reaches to $20 \%$ following treatment with the $2000 \mu \mathrm{g}$ / $\mathrm{mL}$ concentration. Comparisons between the leaf extracts following treatment of the MCF-7 cells revealed that the EA extract is more cytotoxic than the $\mathrm{MeOH}$ one yielding a cytotoxic difference of $56 \%$ as recorded following treatment with $2000 \mu \mathrm{g} / \mathrm{mL}$ concentration $(\mathrm{P}<0.0001)$. When treated on the AGS cell line, the EA extract was even more cytotoxic than $\mathrm{MeOH}$ one, caus- ing $69.9 \%$ more cell death at $2000 \mu \mathrm{g} / \mathrm{mL}$ concentration $(\mathrm{P}<0.0001)$. Results of the comparative cytotoxic effects of the fruit $\mathrm{MeOH}$ and EA extracts were somehow similar to those of the leaf extracts. However, the fruit EA extract was even more cytotoxic than the leaf EA extract. The fruit EA extract caused $56.03 \%$ and $64.7 \%$ more cell death of the MCF-7 and AGS cell lines, respectively, at $2000 \mu \mathrm{g} / \mathrm{mL}$ concentration compared to the fruit $\mathrm{MeOH}$ extract $(\mathrm{P}<0.0001)$. The $10 \mu \mathrm{g} / \mathrm{mL}$ concentration of the fruit EA extract caused $35.3 \%$ death of the AGS cells.

Likewise, the comparative analysis showed that the EA extracts of the leaf and the fruit are more cytotoxic than those of the $\mathrm{MeOH}$ one, with the leaf EA extract IC50 values of 65 and $50 \mu \mathrm{g} / \mathrm{mL}$ and the fruit EA extract IC50 values of 58 and $50 \mu \mathrm{g} / \mathrm{mL}$ both on MCF-7 and AGS cells, respectively $(\mathrm{P}<0.0001)$ (Table 1$)$. The $\mathrm{MeOH}$ extracts of the leaf and the fruit had low cytotoxicity, causing an approximately $20 \%$ reduction in cell viability at $2000 \mu \mathrm{g} / \mathrm{mL}$ concentration. 

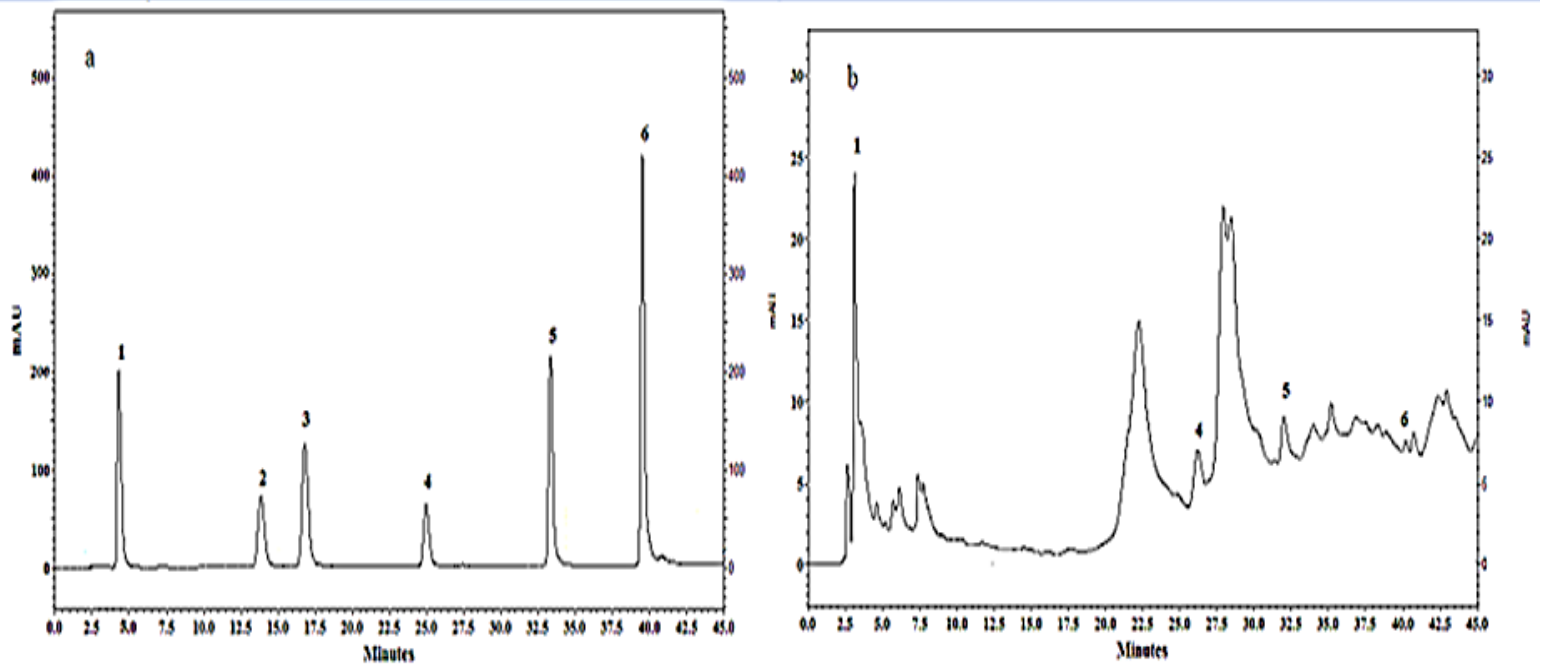

grmm

Figure 2. HPLC chromatograms of the phenolic compounds from the standard samples and determined in the extracts at $275 \mathrm{~nm}$ The $x$-axis represents retention time (minutes) and the y-axis represents mAU (milli-Absorbance Unit). A: Standards; b: Extract; 1 , garlic acid; 2 , chlorogenic acid; 3 , caffeic acid; 4 , p-coumaric acid; 5 , rutin; 6 , quercetin.

The HPLC analysis was conducted at $25^{\circ} \mathrm{C}$ with a flow rate of $1 \mathrm{~mL} / \mathrm{min}$ for quantitative separation of the phenolic compounds from the extracts. The retention times and the UV spectral peaks of the authentic standard compounds were intended to detect the contents of the extracts (Figure $2 \mathrm{~A}, \mathrm{~B}$ ). The standard samples included gallic acid, caffeic acid, p-coumaric, rutin acid, and quercetin provided from Sigma-Aldrich company. Phenolic content from the sample extracts was collected during the time 0 up to $45 \mathrm{~min}$ and resolved considering the peak area of corresponding concentrations of the sample and standard. Three phenolic compounds, including $\mathrm{p}$ coumaric acid $(0.10 \mathrm{mg} / \mathrm{g}$ of powder), rutin $(0.07 \mathrm{mg} / \mathrm{g}$ of powder), and quercetin $(0.02 \mathrm{mg} / \mathrm{g}$ of powder), were detected in the extracts.

Results of the MTT test were further analyzed using the Quest Graph ${ }^{\mathrm{TM}}$ IC50 Calculator1, and the resulting graph and its line equation were presented in Figure 3.

\section{Discussion}

Breast and stomach cancers are the leading malignancies in Iranian females and males, respectively. Epidemiological studies show that the incidence and mortality rates of these two cancers are increasing in Iran, specifi-

$$
\text { 1. https://www.aatbio.com/tools/ic50-calculator }
$$

Table 1. Statistical analysis of the cytotoxicity of the leaf and the fruit ethyl-acetate and methanolic extracts of Sambucus ebulus L. on MCF7 and AGS cell line

\begin{tabular}{cccc}
\hline Extracts & Mean Square & F Ratio & $\mathbf{P}^{*}$ \\
\hline Leaf ethyl-acetate extract on MCF-7 & 1475.943 & 913.745 & $<0.0001$ \\
\hline Leaf ethyl-acetate extract on AGS & 1778.138 & 624.064 & $<0.0001$ \\
\hline Leaf methanol extract on MCF-7 & 128.155 & 53.070 & $<0.0001$ \\
\hline Leaf methanol extract on AGS & 139.409 & 514.287 & $<0.0001$ \\
\hline Fruit ethyl-acetate extract on MCF-7 & 1615.202 & 700.440 & $<0.0001$ \\
\hline Fruit ethyl-acetate extract on AGS & 1403.948 & 1123.881 & $<0.0001$ \\
\hline Fruit methanol extract on MCF-7 & 130.351 & 464.208 & $<0.0001$ \\
\hline Fruit methanol extract on AGS & 137.982 & 580.539 & $<0.0001$ \\
\hline
\end{tabular}

${ }^{\bar{P}}<0.05$ is considered statistically significant. 


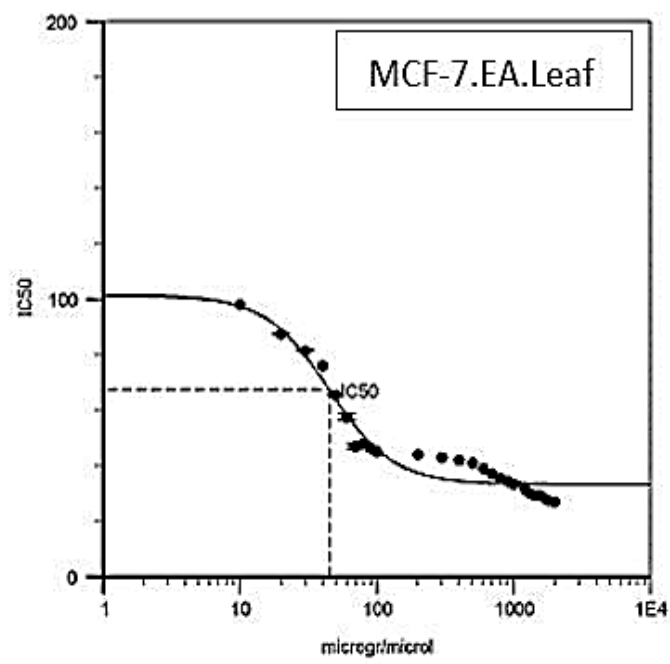

$I C_{50}=47.208$

$y=29.431 \div \frac{(98.440-29.431)}{1+\left(\frac{x}{47.208}\right)^{2719}}$

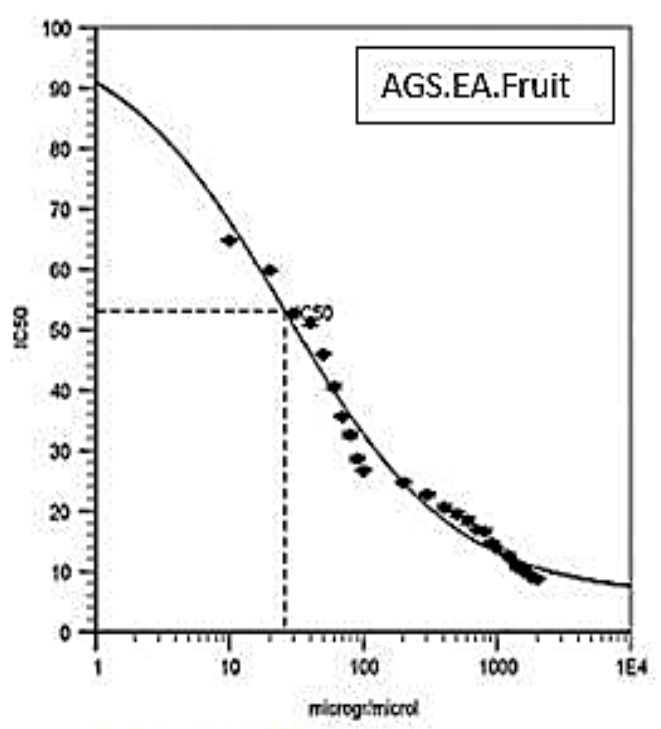

$1 C_{50}=26.159$

$$
y=6.019+\frac{(99.930-6.019)}{1+\left(\frac{x}{26.159}\right)^{0.686}}
$$

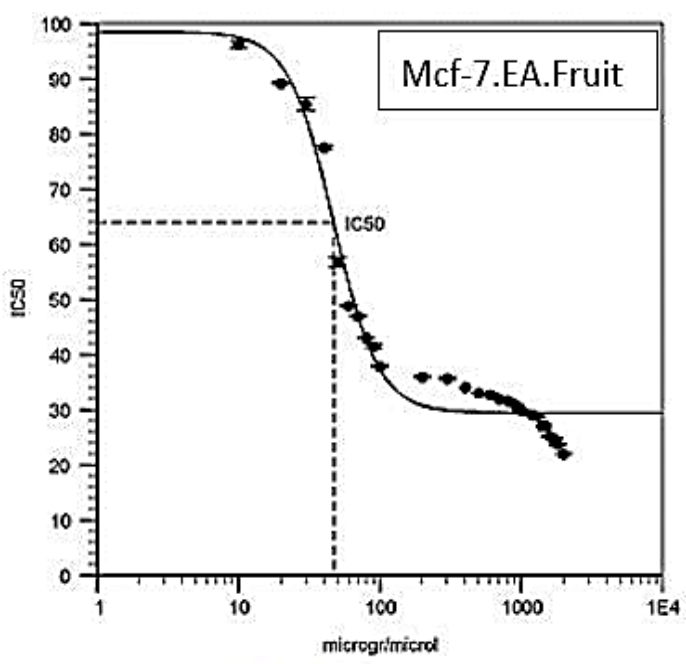

$I C_{50}=45.098$

$$
y=33.221+\frac{(101.314-33.221)}{1+\left(\frac{x}{45.098}\right)^{1.84 B}}
$$

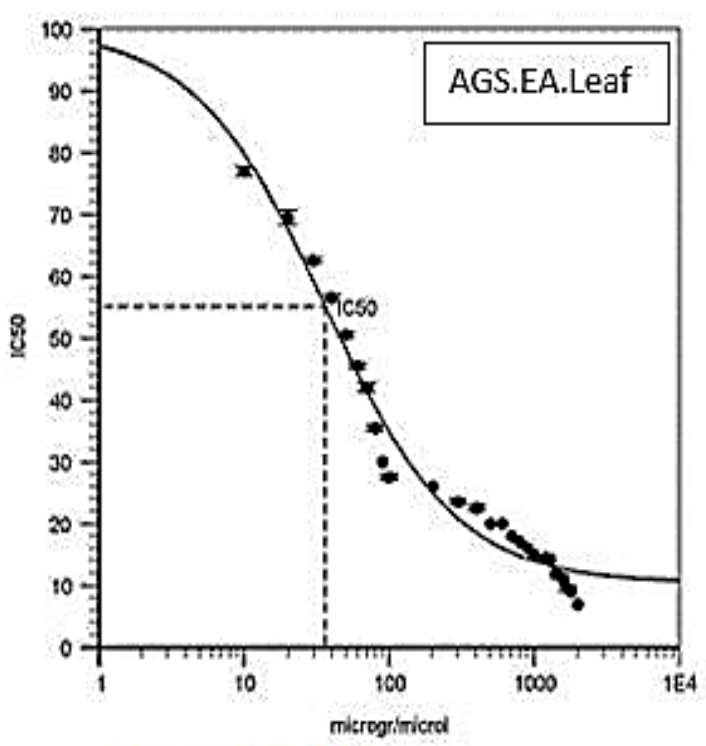

$I C_{50}=36.345$

$y=10.354+\frac{(99.980-10.354)}{1+\left(\frac{x}{36.345}\right)^{0.959}}$ 


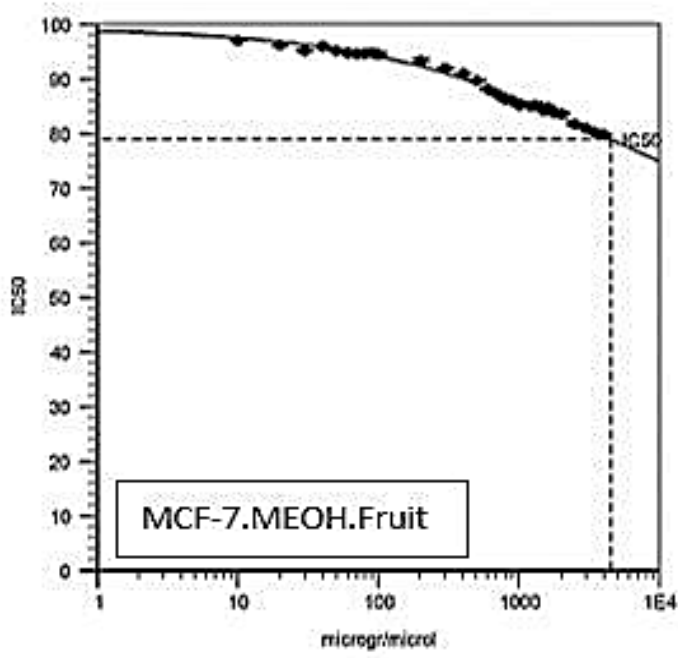

$I C_{50}=4536.220$

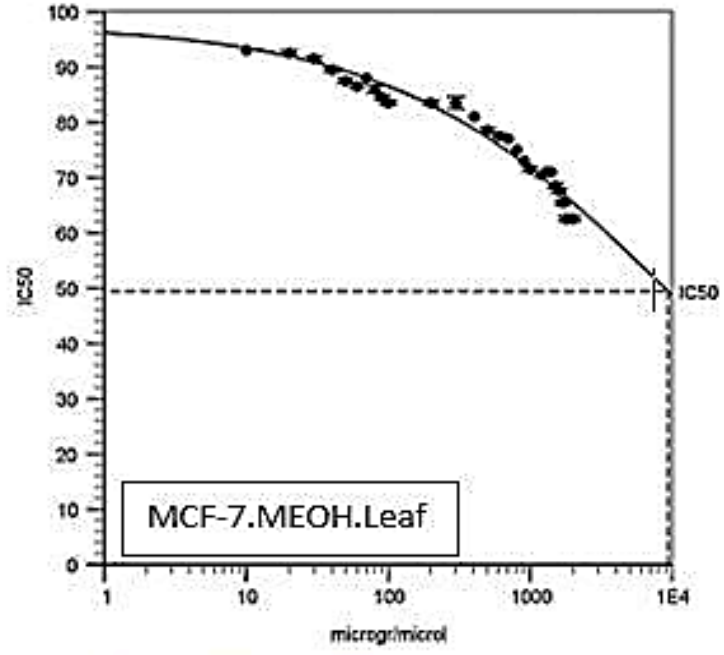

$I C_{50}=9314.467$

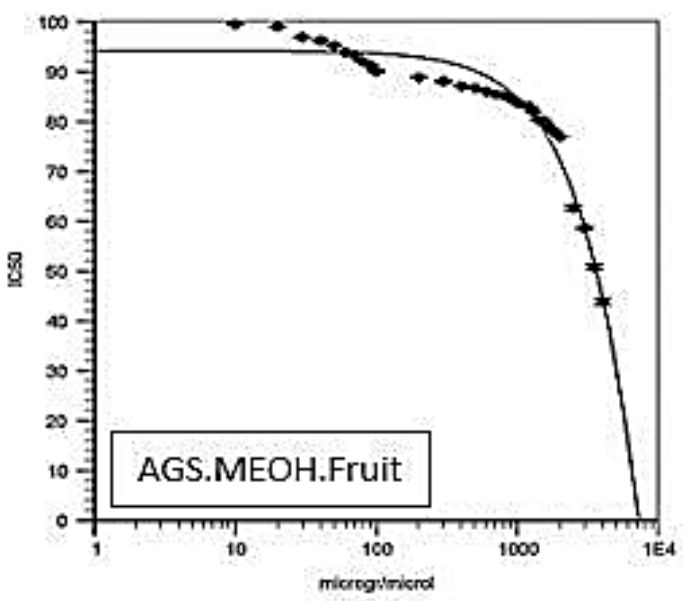

$I_{50}=7297.321$

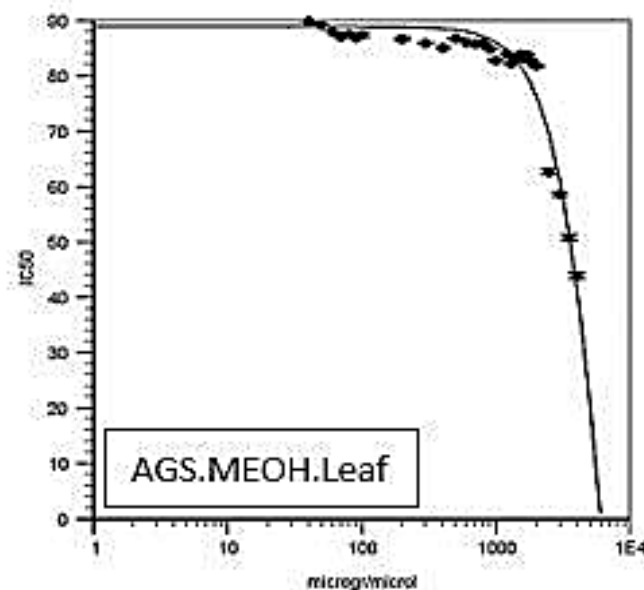

$I C_{50}=24988.840$

Figure 3. The results of the Quest Graph ${ }^{\mathrm{TM}} \mathrm{IC} 50$ Calculator show the regression diagram of the concentration of each extract and the percentage of IC50 and line equation

The x-axis shows the concentration of the extract in micrograms per milliliter, and the y-axis shows the percentage of IC50. 
cally in the northern and the northwestern parts [1, 4-6, 25]. Preliminary studies conducted by different research groups show that an increase of the proven risk factors such as lifestyle and environmental xenobiotics like pesticide exposure might be involved in tumorigenesis mainly through epigenetic modifications of essential genes regulating cell homeostasis [2, 10, 32, 33]. Dwarf elder contains antioxidant phytochemicals helping to stabilize cell homeostasis. Here, we report cytotoxicity of an integrative concentration range $(10-2000 \mu \mathrm{g} / \mathrm{mL})$ of the fruit and the leaf EA and $\mathrm{MeOH}$ extracts of $\mathrm{S}$. ebulus on MCF-7 and AGS cells. The leaf EA extract showed IC50 of 65 and $50 \mu \mathrm{g} / \mathrm{mL}$ for MCF7 and AGS cells, respectively. However, the $\mathrm{MeOH}$ extract of the leaves had low cytotoxic activity, causing a maximum growth arrest of $20 \%$ with the $2000 \mu \mathrm{g} / \mathrm{mL}$ concentration.

Similarly, the EA extract of the fruits was more cytotoxic compared to its $\mathrm{MeOH}$ extract, with IC50 values of 58 and $50 \mu \mathrm{g} / \mathrm{mL}$ on MCF-7 and AGS cells, respectively. The fruit $\mathrm{MeOH}$ extract showed low toxicity, causing approximately 20\% growth arrest against both MCF7 and AGS cells at the highest concentration. The EA extracts are more cytotoxic than the $\mathrm{MeOH}$ extract yielding cytotoxic activity of $56 \%$ on MCF-7 cells with the leaf extract and $69.9 \%$ on AGS cells with the fruit extract as recorded following treatment with the $2000 \mu \mathrm{g} / \mathrm{mL}$ concentration. In another study, the EA extracts of the fruits showed the highest cytotoxicity, reducing $35.3 \%$ cell viability at $10 \mu \mathrm{g} / \mathrm{mL}$ concentration.

Cytotoxicity of the fruit EA extract from $S$. ebulus was investigated on HepG2 and CT26 cancer cell lines and compared with those of the normal $\mathrm{CHO}$ and fibroblast cells [33]. IC50 Mean \pm SD values of $97.03 \pm 1.52$ and $152.70 \pm 3.36 \mu \mathrm{g} / \mathrm{mL}$ were recorded against HepG2 and CT26 cells, respectively that are greater than those reported for the normal cells. Likewise, the antioxidant and anticarcinogenic activities of the $\mathrm{MeOH}$ extracts of flowers, fruits, and leaves of S. ebulus were evaluated on mouse fibroblast (L929) and HeLa human cervix adenocarcinoma cell lines [34]. A maximum growth inhibition rate of $33.81 \%$ was documented following treatment of HeLa cells with $10 \mu \mathrm{g} / \mathrm{mL}$ of the leaf extract [33]. The cytotoxic effects of 16 medicinal plants extracted with n-hexane, dichloromethane, $\mathrm{MeOH}$, and water were tested against AGS, HT-29, and MDA-MB-435S cells. All extracts showed differential cytotoxic activities, among which the $\mathrm{MeOH}$ extract of Blumea lacera showed IC50 of 30 and $80 \mu \mathrm{g} / \mathrm{mL}$ on the AGS and breast cancer cells [30, 33, 34].

Similar to the present research results, the AGS cells had more susceptibility than the breast cancer cells. Polar solvents show the best antioxidant activity for trapping free radicals, DPPH, and nitric oxide, as well as in reduction tests. They allow preferential extraction of phenolic compounds. By contrast, non-polar solvents such as chloroform, n-butanol, and EA are suitable for the extraction of flavonoids. EA is an adequate solvent for the extraction of higher amounts of flavonoids either solely in a single step or in successive steps together with other solvents [9]. This effect may explain the higher cytotoxic values of the EA extracts as documented in the present research. The main outlook in this project was to search for the concentration range/s which would decrease or stop the proliferation of the cells without killing them. Keeping in mind that, as a side effect in most pharmacotherapy methods, the therapeutic drug would affect both the normal and cancerous cells, treatment with the concentration of the plant extract inhibiting proliferation of the tumor is the most priority in cancer treatment. The $\mathrm{MeOH}$ extracts showing low or negative cytotoxicity at most tested concentrations would be the promising compounds to prevent cell proliferation without killing them. However, there are some shortcomings in this research, as the absence of the anticancer drug as positive control and comparing the behavior of the cancer cells with that of the normal one. It is particularly recommended that the effects of the purified phenolic compounds potentially responsible for the anticancer activity of S. ebulus extracts be studied on normal and cancerous cell lines to gain inclusive results.

\section{Conclusion}

Our findings suggest that the S. ebulus extracts are particularly rich with phenolic compounds, including $\mathrm{p}$ coumaric acid, rutin, and quercetin, possibly modulating their beneficial use for breast and gastric malignancies.

\section{Ethical Considerations}

\section{Compliance with ethical guidelines}

This study was approved by the Ethics Committee of Mazandaran University of Medical Sciences (Code: IR.MAZUMS.REC.1398.574)

\section{Funding}

This research was supported by Sari Agricultural Sciences and Natural Resources University and Mazandaran University of Medical Sciences (Grant No: IR.MAZUMS REC.1393.1305). 


\section{Authors' contribution}

Conceptualization and supervision: Ali Barzegar; Methodology: Ali Barzegar and Mohammad Ali Ebrahimzadeh; Investigation, writing- original draft, and writing- review \& editing: Ali Barzegar, Mohammad Ali Ebrahimzadeh, and Farzaneh Rasouli Asl; Data collection: Farzaneh Rasouli Asl; Data analysis: Mohammad Ali Ebrahimzadeh, Ali Barzegar, Farzaneh Rasouli Asl; Funding acquisition and resources: Farzaneh Rasouli Asl, Ali Barzegar, Mohammad Ali Ebrahimzadeh.

\section{Conflict of interest}

The authors declared no conflict of interest.

\section{Acknowledgments}

The authors thank Ayoub Farhadi and Mohammad Ali Rohi for providing some lab facilities and their assistance in MTT analysis.

\section{References}

[1] Mohammadi E, Aminorroaya A, Fattahi N, Azadnajafabad S, Rezaei N, Farzi Y, et al. Epidemiologic pattern of cancers in Iran; current knowledge and future perspective. J Diabetes Metab Disord. 2020; 20:1-5. [DOI:10.1007/s40200-020-00654-6]

[2] Sadeghi-Amiri L, Barzegar A, Rafiei A, Amjadi O. An overview of the epigenetic modifications of gene expression in tumorigenesis. Res Mol Med. 2018; 6(3):1-19. http://rmm.mazums. ac.ir/article-1-295-fa.html

[3] Kolah DS, Sajadi AR, Radmard AR, Khademi H. Five common cancers in Iran. Arch Iran Med. 2010; 13(2):143-6. https:/ / www. sid.ir/en/Journal/ViewPaper.aspx?ID=168243

[4] Saadat S, Yousefifard M, Asady H, Moghadas Jafari A, Fayaz $\mathrm{M}$, Hosseini M. The most important causes of death in Iranian population; a retrospective cohort study. Emerg (Tehran). 2015; 3(1):16-21. [PMID] [PMCID]

[5] Kamalipour S, Barzegar A, Shokrzadeh M, Nikbakhsh N. Increased expression of CYP2E1 gene in gastric cancer may be a molecular marker for Mazandaran Province population. J Genet Resour. 2017; 3(2):130-6. http://sc.journals.umz.ac.ir/ article_1757_329.html

[6] Moghaddam SE, Barzegar A, Nikbakhsh N. Study of the regulatory promoter polymorphism $(-938 \mathrm{C}>\mathrm{A})$ of B-cell lymphoma 2 gene in breast cancer patients of Mazandaran Province in Northern Iran. J Res Med Sci. 2017; 22:21. [DOI:10.4103/17351995.200269] [PMID] [PMCID]

[7] Heer E, Harper A, Escandor N, Sung H, McCormack V, FidlerBenaoudia MM. Global burden and trends in premenopausal and postmenopausal breast cancer: A population-based study.
Lancet Glob Health. 2020; 8(8):e1027-37. [DOI:10.1016/S2214109X(20)30215-1]

[8] Dartois L, Fagherazzi G, Boutron-Ruault MC, Mesrine S, ClavelChapelon F. Association between five lifestyle habits and cancer risk: Results from the E3N Cohort. Cancer Prev Res (Phila). 2014; 7(5):516-25. [DOI:10.1158/1940-6207.CAPR-13-0325] [PMID]

[9] Engel LS, Werder E, Satagopan J, Blair A, Hoppin JA, Koutros $\mathrm{S}$, et al. Insecticide use and breast cancer risk among farmers wives in the agricultural health study. Environ Health Perspect. 2017; 125(9):097002. [DOI:10.1289/EHP1295] [PMID] [PMCID]

[10] Khalili Tanha G, Barzegar A, Shokrzadeh M, Nikbakhsh N, Ansari Z. Correlation between serum concentration of diazinon pesticide and breast cancer incidence in Mazandaran Province, Northern Iran. Caspian J Environ Sci. 2020; 18(3):197-204. https://cjes.guilan.ac.ir/article_4132.html

[11] Hanahan D, Folkman J. Patterns and emerging mechanisms of the angiogenic switch during tumorigenesis. Cell. 1996; 86(3):353-64. [DOI:10.1016/S0092-8674(00)80108-7]

[12] Citores L, de Benito FM, Iglesias R, Miguel Ferreras J, Argüéso $\mathrm{P}$, Jiménez $\mathrm{P}$, et al. Presence of polymerized and free forms of the non-toxic type 2 ribosome-inactivating protein ebulin and a structurally related new homodimeric lectin in fruits of Sambucus ebulus L. Planta. 1998; 204(3):310-9. [DOI:10.1007/ s004250050261] [PMID]

[13] Naghibi S A, Shojaizadeh D, Montazeri A, Yazdani Cherati J. [Epidemiology of breast cancer in Mazandaran Province, 20092010 (Persian)]. J Mazandaran Univ Med Sci. 2013; 23(102):112-9. http://jmums.mazums.ac.ir/article-1-2392-en.html

[14] Jabbari M, Daneshfard B, Emtiazy M, Khiveh A, Hashempur $\mathrm{MH}$. Biological effects and clinical applications of dwarf elder (Sambucus ebulus L): A review. J Evid Based Complementary Altern Med. 2017; 22(4):996-1001. [DOI:10.1177/2156587217701322] [PMID] [PMCID]

[15] Feizbakhsh A, Pazoki H, Ebrahimzadeh MA. Sambucus ebulus: Introduction to mechanism of action: A chemical viewpoint Pharmacologyonline. 2010; 1:16-22. https:// pharmacologyonline.silae.it/files/youngresearchers/2010/vol1/3.Pazoki.pdf

[16] Ebrahimzadeh MA, Ehsanifar S, Eslami B. Sambucus ebulus elburensis fruits: A good source for antioxidants. Pharmacogn Mag. 2009; 5(19):213-8. https:/ / www.phcog.com/article asp?issn $=0973-1296$; year $=2009 ;$;olume $=5$;issue $=19 ;$;page $=213$; epage $=218$; aulast $=$ Ebrahimzadeh

[17] Shokrzadeh M, Saravi SS. The chemistry, pharmacology and clinical properties of Sambucus ebulus: A review. J Med Plants Res. 2010; 4(2):95-103. https://academicjournals.org/article/ article1380375358_Shokrzadeh\%20and\%20Saravi.pdf

[18] Benítez J, Rojo MA, Muñoz R, Ferreras JM, Jiménez P, Girbes $\mathrm{T}$. Design and cytotoxicity analysis of a conjugate containing the new dgalactose-binding lectin selld and the non-toxic type 2 ribosome-inactivating protein nigrin $b$. Lett Drug Des Discov. 2004; 1(4):361-7. [DOI:10.2174/1570180043398687]

[19] Ebrahimzadeh MA, Mahmoudi M, Karami M, Saeedi S, Ahmadi AH, Salimi E. Separation of active and toxic portions in Sambucus ebulus. Pak J Biol Sci. 2007; 10(22):4171-3. [DOI:10.3923/ pjbs.2007.4171.4173] [PMID]

[20] Cai Y, Luo Q, Sun M, Corke H. Antioxidant activity and phenolic compounds of 112 traditional Chinese medicinal plants 
associated with anticancer. Life Sci. 2004; 74(17):2157-84. [DOI:10.1016/j.lfs.2003.09.047] [PMID] [PMCID]

[21] Huang WY, Cai YZ, Zhang Y. Natural phenolic compounds from medicinal herbs and dietary plants: Potential use for cancer prevention. Nutr Cancer. 2009; 62(1):1-20. [DOI:10.1080/01635580903191585] [PMID]

[22] Mirmajidi SH, Barzegar A, Nikbakhsh N. [Study of regulatory promoter polymorphism (-938 C> A) of Bcl2 gene in patients with gastric cancer (Persian)]. J Mazandaran Univ Med Sci. 2016; 26(142):50-9. http://jmums.mazums.ac.ir/files/site1/ user_files_Od0bf0/mousavi-A-10-29-447-41d22ab.pdf

[23] Mousavi SM, Gouya MM, Ramazani R, Davanlou M, Hajsadeghi N, Seddighi Z. Cancer incidence and mortality in Iran. Ann Oncol. 2009; 20(3):556-63. [DOI:10.1093/annonc/mdn642] [PMID]

[24] Khalili M, Ebrahimzadeh MA, Kosaryan M, Abbasi A, Azadbakht M. Iron chelation and liver disease healing activity of edible mushroom (Cantharellus cibarius), in vitro and in vivo assays. RSC Adv. 2015; 5(7):4804-10. [DOI:10.1039/C4RA11561A]

[25] Torre LA, Bray F, Siegel RL, Ferlay J, Lortet-Tieulent J, Jemal A. Global cancer statistics, 2012. CA Cancer J Clin. 2015; 65(2):87108. [DOI:10.3322/caac.21262] [PMID]

[26] Siegel RL, Miller KD, Jemal A. Cancer statistics, 2015. CA Cancer J Clin. 2015; 65(1):5-29. [DOI:10.3322/caac.21254] [PMID]

[27] Ebrahimzadeh MA, Nabavi SF, Nabavi SM. Antioxidant activities of methanol extract of Sambucus ebulus L. flower. Pak J Biol Sci. 2009; 12(5):447-50. [DOI:10.3923/pjbs.2009.447.450] [PMID]

[28] Lak E, Ranjbar R, Najafzadeh H, Morovvati H, Khaksary M Protective effect of Sambucus elbus extract on teratogenicity of albendazole. World Appl Sci J. 2011; 15(5):643-6. https:/ /citeseerx.ist.psu.edu/viewdoc/download?doi=10.1.1.389.4252\&rep= rep1\&type $=$ pdf

[29] Jiménez P, Tejero J, Cordoba-Diaz D, Quinto EJ, Garrosa M, Gayoso MJ, et al. Ebulin from dwarf elder (Sambucus ebulus L.) A mini-review. Toxins (Basel). 2015; 7(3):648-58. [DOI:10.3390/ toxins7030648] [PMID] [PMCID]

[30] Azwanida NN. A review on the extraction methods uses in medicinal plants, principle, strength and limitation. Med Aromat Plants. 2015; 4(3):1000196. https://www.longdom.org/openaccess/a-review-on-the-extraction-methods-use-in-medicinalplants-principle-strength-and-limitation-2167-0412-1000196.pdf

[31] Sebaugh JL. Guidelines for accurate EC50/IC50 estimation. Pharm Stat. 2011; 10(2):128-34. [DOI:10.1002/pst.426] [PMID]

[32] Saravi SS, Shokrzadeh M, Hosseini Shirazi F. Cytotoxicity of Sambucus ebulus on cancer cell lines and protective effects of vitamins $\mathrm{C}$ and $\mathrm{E}$ against its cytotoxicity on normal cell lines. Afr J Biotechnol. 2013; 12(21):3360-5. https://www.ajol.info/index. php/ajb/article/view/132004

[33] Meriç Z, Bitiş L, Tan SB, Turan SÖ, Akbuga J. Antioxidant, antimicrobial and anticarcinogenic activities of Sambucus ebulus L. flowers, fruits and leaves. Marmara Pharm J. 2014; 18(1):22-5. [DOI:10.12991/mpj.2014184122]

[34] Uddin SJ, Grice ID, Tiralongo E. Cytotoxic effects of bangladeshi medicinal plant extracts. Evid Based Complement Alternat Med. 2011; 2011:578092. [DOI:10.1093/ecam/nep111] [PMID] [PMCID] 